\title{
Incidence of Anterior Uveitis in Patients with Axial Spondyloarthritis Treated with Anti-TNF or Anti- IL17A: A Systematic Review, A Pairwise and Network Meta-Analysis of Randomized Controlled Trials
}

\section{Damien Roche}

Assistance Publique - Hôpitaux de Marseille https://orcid.org/0000-0002-8230-3085

\section{Martin Badard}

AP-HM: Assistance Publique Hopitaux de Marseille

\section{Laurent Boyer}

AP-HM: Assistance Publique Hopitaux de Marseille

\section{Pierre Lafforgue}

AP-HM: Assistance Publique Hopitaux de Marseille

Thao Pham ( $\square$ thao.pham@ap-hm.fr)

AP-HM: Assistance Publique Hopitaux de Marseille

\section{Research article}

Keywords: Axial spondyloarthritis, meta-analysis, anti-TNF, anti-IL17A, uveitis

Posted Date: November 12th, 2020

DOI: https://doi.org/10.21203/rs.3.rs-103580/v1

License: (c) (i) This work is licensed under a Creative Commons Attribution 4.0 International License.

Read Full License

Version of Record: A version of this preprint was published at Arthritis Research \& Therapy on July 16th, 2021. See the published version at https://doi.org/10.1186/s13075-021-02549-0. 


\section{Abstract}

Background: Anterior uveitis (AU) is the most frequent extra-articular feature of axial spondyloarthritis (axSpA). We aimed to assess and compare the incidence of AU in axSpA patients treated with anti-TNF or anti-IL17A.

Methods: We systematically reviewed PubMed, EMBase and Cochrane from inception to May 3, 2020, and searched for placebo-controlled and head-to-head randomized controlled trials (RCTs) assessing anti-TNF monoclonal antibodies (mAb) or soluble receptor fusion protein or anti-IL17A in patients with axSpA according to ASAS criteria and reporting safety data on AU. Data were extracted following a predefined protocol. We did pairwise and network meta-analyses for the primary outcome of AU flares (relapse or de novo) incidence and estimated summary odds ratios (ORs). We assessed the quality of evidence using the Cochrane risk-of-bias 2.0 tool. We ranked treatments according to their effectiveness in preventing $\mathrm{AU}$ flare using the P-score.

Results: We identified 752 citations and included 33 RCTs, comprising 4544 treated patients (anti-TNF mAb: 2101, etanercept [ETN]: 699, anti-IL17A: 1744) and 2497 placebo-receiving patients. Incidence of uveitis was lower with anti-TNF mAb versus placebo (OR $=0.46$; CI95\% $[0.24 ; 0.90])$ and versus anti-IL17A $(\mathrm{OR}=0.34 ; \mathrm{Cl} 95 \%[0.12 ; 0.92]$. According to the P-score, the ranking from the most to the least preventive treatment of uveitis flare was as follows: anti-TNF mAb, ETN, placebo, anti-IL17A.

Conclusion: In RCTs assessing anti-TNF and anti-IL17A in axSpA, incident uveitis are rare events. However, this network meta-analysis demonstrates that anti-TNF mAb are associated with a lower incidence of uveitis compared to placebo and anti-IL17A.

\section{Background}

Axial spondyloarthritis [axSpA] is a chronic inflammatory disease that mainly affects the axial skeleton. AxSpA can be classified into two subgroups: ankylosing spondylitis [AS] and non-radiographic axSpA [nr$\operatorname{axSpA]}(1,2)$. The most frequent extra-articular manifestation associated with axSpA is anterior uveitis [AU] which occurs in $23 \%$ (3) $-33 \%$ (4) of patients with AS, and in $16 \%$ of patients with nr-axSpA (3).

Biologics therapy has dramatically changed the management of axSpA and its associated extra-articular manifestations. Two classes of biologics have demonstrated their efficacy for the treatment of axSpA: the tumor necrosis factor inhibitors [anti-TNF] including four anti-TNF monoclonal antibodies [mAb]: infliximab [IFX], adalimumab [ADA], golimumab [GOL], certolizumab [CTZ] and one soluble receptor fusion: etanercept [ETN], and the interleukin-17A inhibitors [anti-IL17A] including secukinumab [SCK] and ixekizumab [IXE].

The efficacy of biologics on axSpA-associated AU is less well known. Among anti-TNF mAb, ADA has been shown to significantly reduce the risk of non-infectious uveitic flare, associated or not with axSpA, in two placebo-controlled RCTs (5)'(6). Several observational studies and post-hoc analysis from placebo- 
controlled studies focused on axSpA-associated AU and showed that the incidence of AU decreases after treatment with anti-TNF mAb compared to the incidence before treatment(7-13). These studies mainly involved IFX and ADA. However, a meta-analysis of 8 RCTs concluded that anti-TNF mAb were not associated with fewer AU flares, including relapses and new onset, than placebo (14).

The effect of receptor fusion proteins including ETN on AU associated with axSpA is even more unclear. The before/after treatment rates of AU in 1365 patients with AS from the Swedish biologics register concluded to a significant increase with ETN(9), also other observational studies did not observe any difference $(7,15)$. At the opposite, Wu et al. reported a preventive effect of ETN for flares [relapse or new onset] of uveitis in AS patients in their meta-analysis(14).

Data is scarce on anti-IL17A on axSpA-associated AU or HLA-B27-associated AU. Two randomized, double-blinded, placebo-controlled studies assessing the efficacy of SCK in non-infectious non-Behcet's uveitis showed no difference in the recurrence rate or in reducing intraocular inflammation versus placebo (16). A pooled data analysis of three RCTs reviewed 794 patients, of whom 135 had uveitis history, and reported an exposure adjusted incidence rate of 0.03 per 100 patients-years(17). Information on the impact of the other anti-IL17A on uveitis flares are expected.

Thus, association between biologic in axSpA and AU manifestations remains poorly defined. Therefore, we aimed to conduct a systematic review, a pairwise and a network meta-analysis to help clinical practice by comparing different biologics on their protecting effect on AU flares.

\section{Methods}

\section{Data sources and search strategy}

A systematic search of the literature was conducted in MEDLINE [via PubMed], EMBase and the Cochrane Library from inception to May 3, 2020.

We used the following search strategy in PubMed: ["spondylitis, ankylosing" [MeSH Terms] OR spondylart*[tiab] OR spondyloa*[tiab]] AND ["infliximab" [MeSH Terms] OR "certolizumab pegol" [MeSH Terms] OR "etanercept" [MeSH Terms] OR "adalimumab" [MeSH Terms] OR "golimumab" [tw] OR "secukinumab" [tw] OR "ixekizumab" [tw] OR "infliximab" [tw] OR "certolizumab" [tw] OR "etanercept" [tw] $O R$ "adalimumab" [tw]] AND "randomized"] and the following search strategy in EMBase: ["ankylosing spondylitis"/exp OR "axial spondylarthritis"/exp OR "spondylarthritis"/exp] AND ["etanercept"/exp OR "infliximab"/exp OR "adalimumab"/exp OR "golimumab"/exp OR "certolizumab pegol"/exp OR certolizumab OR "secukinumab"/exp OR "ixekizumab"/exp] AND ["randomized controlled trial"/de].

Our search concerned articles published in English. A hand search was also performed. Finally, we collected data from electronic abstract databases of the annual scientific meetings of the EUropean League Against Rheumatism Rheumatology congress and the American College of Rheumatology from 2016 to 2019. 


\section{Study selection}

Two authors [DR, MB] independently determined the eligibility of the studies after reading title, keywords and abstract. Discrepancy was resolved by consensus.

We pre-specified the target population, interventions, comparators, outcome measures of interest, timing, following the PICOTs framework.

Inclusion criteria for full text were: 1) RCT published in English before May 3, 2020; 2) comparing the efficacy of any anti-TNF or anti-IL17A versus a comparator (placebo or another active treatment); 3 ) in a study population of patients with axSpA according to the Assessment of SpondyloArthritis International Society (ASAS) (18) or modified New York (mNY) criteria; 4) with data provided on the number of AU occurring during the controlled period in the safety chapter.

We applied the following exclusion criteria in a sequential order: 1) duplicates (between 2 electronic databases, or in a same electronic database but between 2 different journals), 2) language not English, 3) off topic, 4) design other than RCT, 5) population (not axSpA, or patients under the age of 18 , or wrong classification criteria), 6) inadequate comparison and 7) inadequate safety data reporting (adverse events had to be noticed during the controlled period, separately from the open-label extension).

We considered all five currently available anti-TNF (ADA, ETN, IFX, GOL, CTZ) and two anti-IL17A (SCK, IXE). We included open-labeled controlled studies only if they included an initial double-blind period with detailed safety analysis during this period.

\section{Data Extraction and Study Quality Assessment}

Two investigators (DM, MB) independently extracted all data using a standardized spreadsheet and assessed the quality of evidence using the Cochrane risk-of-bias (RiOB) 2.0 tool. Discrepancy was resolved by consensus. For each article, we collected according a pre-specified strategy the following information: age and gender, disease symptoms duration, percentage of history of uveitis, concomitant use of conventional synthetic disease-modifying antirheumatic drugs (csDMARDs), corticosteroids or NSAIDs at baseline, study design, inclusion criteria, dosage and schedule of the treatment, duration of the RCT and/or of the double-blind period and sample size. For all extracted data, a central value (mean or median) and variability (standard deviation or interquartile range) were collected.

\section{Outcomes}

Our primary outcome was the AU flares incidence, including relapses and new onsets. We collected the number of AU for each clinical trial and each group of treatment and control, by taking into account the safety population. We took into account the terms "uveitis", "iritis" for AU events. For the studies including a double-blind period and an open-labeled period, only the data from the double-blind period were extracted.

\section{Statistical analyses}




\section{Pairwise meta-analysis}

We realized a pairwise meta-analysis with fixed-effect models and we directly compared the risk of AU events of each biologic treatment, categorized by anti-TNF mAb, ETN and anti-IL17A to placebo. We also conducted supplementary subgroups analysis: a) According to the axSpA phenotype: RCTs with only patients with AS according to the mNY criteria versus RCTs including both nr-axSpA and AS patients according to the ASAS criteria; b) According to the disease duration: RCTs with only early axSpA, i.e. $<5$ years since onset of symptoms, versus RCTs with non-early axSpA; $c$ ) According to the trial quality: RCTs with overall low risk of bias using the Cochrane RiOB 2.0 Tool versus RCTs with moderate or high risk of bias and d) According to the focus on AU: RCTs with mentioned AU history versus RCTs without detailed information on AU history.

We measured heterogeneity across studies using the Cochran's $Q$ test, and 12 statistic, with higher values reflecting increasing heterogeneity. We assessed publication bias by examining funnel plots and using the Egger's regression asymmetry test.

The statistical analysis was performed with Comprehensive Meta-Analysis Version 3(19)

\section{Network meta-analysis}

We also conducted a network meta-analysis to perform an adjusted indirect comparison of the investigational treatment arms categorized in 3 different groups of treatment (anti-TNF mAb, ETN and anti-IL17A). Results of these meta-analyses are the odds ratio (OR) of AU events between treatments (i.e., anti-TNF mAb, ETN and anti-IL17A and placebo) with their 95\% confidence interval and the statistical significance level of the comparison. The homogeneity and consistency assumption was based on a generalized Cochran's Q statistic for multivariate meta-analysis. We ranked the efficacy of the 3 different groups of treatment and placebo, using P-scores that measure the mean extent of certainty that a treatment is better than the competing treatment. In our study, the higher the P-score, the more effective the treatment was in preventing AU flares. The assessment of publication bias was made using funnel plots in this multiple treatment comparison.

The statistical analysis was performed using R statistical packages (version 3.2.4) and the meta-library, Netmeta(20).

\section{Results}

\section{Eligible studies}

We identified 751 citations after search in the 3 databases plus one more after search in the congress abstract databases (Fig. 1). After reading titles and abstracts, we excluded 713 abstracts, mainly because of duplicates or off topic studies. After the complete reading, we excluded 6 articles: 4 because AU were not described during the controlled period, 2 for an unrepresentative population. Finally, we included 33 
RCTs (Figs. 1 and 2), allowing 35 comparisons, comprising 4544 patients with axSpA treated with a biologic treatment and 2497 treated with placebo.

\section{Study characteristics}

The Additional File 1 provides detailed characteristics of the 33 RCTs included in the analyses. A comparison of a biologic treatment versus placebo was performed in 32 placebo-controlled RCTs (including one RCT comparing 2 biologic treatments, i.e. IXE and ADA, versus placebo), and in a head-tohead RCT comparing IFX versus ETN. Anti-TNF mAb were assessed in 17 RCTs(21-37) (ADA: 4; CTZ: 2; GOL: 4; IFX: 7), ETN was assessed in $10 \mathrm{RCTs}(36,38-46)$ and anti-IL17A were assessed in 8 RCTs(37, 47-53) (SCZ: 5; IXE: 3). The mean duration of the controlled period was 22.7 weeks \pm 18.5 (SD), median: 16 weeks (range: 6-104 weeks).

According to the Cochrane RiOB 2.0 tool, 16 RCTs had a low risk of bias, 17 RCTs presented some concerns and none had a high risk of bias (Additional File 2).

\section{Characteristics of the patients with axSpA}

The main characteristics of the intention-to-treat (ITT) population are summarized in Table 1. Because our objective was to collect the AU flares, we included in the analysis the safety populations. A total of 7041 patients were included in the analysis, of whom 2497 received a placebo, 2101 were treated with an anti-TNF mAb, 699 with ETN, and 1744 with an anti-IL17A, with a follow-up of 3264 patients-years. The total cumulative exposure under active treatment was 2265 patients-years. 
Table 1

Baseline characteristics of patients with axSpA (ITT population)

\begin{tabular}{|c|c|c|c|c|c|c|c|}
\hline & $\begin{array}{l}\text { Anti- } \\
\text { TNF } \\
\text { mAb }\end{array}$ & $\begin{array}{l}\text { Associated } \\
\text { placebo } \\
\text { population }\end{array}$ & ETN & $\begin{array}{l}\text { Associated } \\
\text { placebo } \\
\text { population }\end{array}$ & $\begin{array}{l}\text { Anti- } \\
\text { IL17A }\end{array}$ & $\begin{array}{l}\text { Associated } \\
\text { placebo } \\
\text { population }\end{array}$ & $\begin{array}{l}\text { Total } \\
\text { placebo } \\
\text { population }\end{array}$ \\
\hline$N$ & 2040 & 1289 & 754 & 485 & 1744 & 877 & 2567 \\
\hline $\begin{array}{l}\text { Gender male } \\
(\%)\end{array}$ & 71.2 & 68.4 & 72.9 & 73.2 & 63.3 & 63.3 & 67.1 \\
\hline Mean age & 36.9 & 37.2 & 39.8 & 39.1 & 41.8 & 42.4 & 38.8 \\
\hline $\begin{array}{l}\text { HLA B27 } \\
\text { positive (\%) }\end{array}$ & $74.4^{*}$ & $83.5^{\star}$ & $76.3^{\star \star}$ & $77.9 *$ & $76.0 *$ & $75.2^{\star}$ & $79.5^{\star}$ \\
\hline $\begin{array}{l}\text { Mean } \\
\text { duration } \\
\text { symptoms } \\
\text { (years) }\end{array}$ & $9.3^{*}$ & $10.2^{\star}$ & 9.7 & 9.5 & 9.9 & 10.2 & $9.8^{*}$ \\
\hline $\begin{array}{l}\text { AU history } \\
(\%)\end{array}$ & 38.6 ** & $21.5^{\star \star}$ & $16.0 *$ & $18.2^{\star}$ & $14.9 * \star$ & 15.4 *夫 & $18.7^{\star \star}$ \\
\hline $\begin{array}{l}\text { IBD history } \\
(\%)\end{array}$ & $4.7 * \star$ & $4.6^{\star \star}$ & $2.4^{\star \star}$ & $3.7^{\star \star}$ & $2.1^{\star \star}$ & $2.1 * \star$ & $3.4^{\star \star}$ \\
\hline $\begin{array}{l}\text { Mean } \\
\text { BASDAI }\end{array}$ & $6.5^{\star}$ & $6.6^{*}$ & $6.1^{\star}$ & $6.0 *$ & 6.9 & 6.9 & $6.6^{\star}$ \\
\hline $\begin{array}{l}\text { Concomitant } \\
\text { csDMARDs } \\
(\%)\end{array}$ & $35.8^{*}$ & $39.1^{*}$ & $33.3^{*}$ & $27.8^{\star}$ & 32.2 & 33.6 & $35.2^{\star}$ \\
\hline $\begin{array}{l}\text { Concomitant } \\
\text { NSAIDs (\%) }\end{array}$ & $85.1^{\star}$ & $84.2^{\star}$ & $85.2^{\star \star}$ & 88.4 * & $84.4^{\star \star}$ & $86.8 * \star$ & $85.2^{\star \star}$ \\
\hline $\begin{array}{l}\text { Concomitant } \\
\text { steroids (\%) }\end{array}$ & $10.00 * \star$ & $9.0 * \star$ & $12.0^{\star \star}$ & $13.0^{\star \star \star}$ & $10.4^{\star}$ & $12.0 *$ & 10.9 ** \\
\hline \multicolumn{8}{|c|}{$\begin{array}{l}\text { axSpA: axial spondyloarthritis; ITT: intention-to-treat; HLA: Human Leucocyte Antigen; AU : Anterior } \\
\text { Uveitis; IBD : Inflammatory Bowel Disease; BASDAI : Bath Ankylosing Spondylitis Disease Activity } \\
\text { Index; csDMARD : conventional synthetic Disease Modifying Anti Rheumatic Drug; NSAIDs : Non- } \\
\text { Steroidal Anti Inflammatory Drugs }\end{array}$} \\
\hline \multicolumn{8}{|c|}{ * $<25 \%$ lacking data } \\
\hline$\star \star>25 \%$ lackir & data & & & & & & \\
\hline
\end{tabular}

The different treatment groups were similar in terms of gender, age, duration of symptoms, Bath Ankylosing Spondylitis Disease Activity Index (BASDAI) at baseline, concomitant csDMARD, non-steroidal anti-inflammatory drugs (NSAIDs) and corticosteroids intake. AU and inflammatory bowel disease (IBD) history were less frequent in the ETN and anti-IL17A groups than in the anti-TNF mAb. 
A total of 69 AU flares (de novo or relapses) was reported during the controlled periods: 31 among placebo-treated patients, 10 among anti-TNF mAb-treated patients (CTZ: 6, IFX: 3 and GOL: 1), 5 among ETN-treated patients and 23 among anti-IL17A-treated patients (SCK: 14 and IXE: 9) (Table 2). Crude annual incidence of AU was $1.06 \%, 2.14 \%, 2.11 \%$ and $3.10 \%$, in the anti-TNF mAb, ETN, anti-IL17A and placebo groups, respectively. 
Table 2

AU Flares reported in the included RCTs

\begin{tabular}{|c|c|c|c|c|c|c|}
\hline & & & Treatmen & & Placebo & \\
\hline First Author & Treatment & $\begin{array}{l}\text { Study duration } \\
\text { (weeks) }\end{array}$ & $\begin{array}{l}\text { Patients } \\
\text { (n) }\end{array}$ & $\begin{array}{l}\text { Uveitis } \\
\text { (n) }\end{array}$ & $\begin{array}{l}\text { Patients } \\
\text { (n) }\end{array}$ & $\begin{array}{l}\text { Uveitis } \\
\text { (n) }\end{array}$ \\
\hline $\begin{array}{l}\text { Van der Heijde } \\
\text { D. }{ }^{26}\end{array}$ & $\mathrm{ADA}$ & 24 & 208 & 0 & 107 & 0 \\
\hline Sieper J. ${ }^{27}$ & ADA & 12 & 95 & 0 & 97 & 0 \\
\hline Huang F. ${ }^{25}$ & $\mathrm{ADA}$ & 12 & 229 & 0 & 115 & 0 \\
\hline Landewé R. ${ }^{31}$ & $\mathrm{CTZ}$ & 24 & 218 & 2 & 107 & 3 \\
\hline Deodhar A. ${ }^{22}$ & CTZ & 52 & 159 & 4 & 158 & 8 \\
\hline Inman R. ${ }^{28}$ & $\mathrm{GOL}$ & 24 & 278 & 0 & 77 & 0 \\
\hline Deodhar A. ${ }^{33}$ & GOL & 16 & 105 & 0 & 103 & 2 \\
\hline Sieper J. ${ }^{23}$ & GOL & 16 & 97 & 0 & 100 & 0 \\
\hline Bao C. ${ }^{34}$ & $\mathrm{GOL}$ & 24 & 169 & 1 & 44 & 0 \\
\hline $\begin{array}{l}\text { Van der Heijde } \\
\text { D. }{ }^{29}\end{array}$ & IFX & 18 & 202 & 0 & 75 & 0 \\
\hline Barkham N. ${ }^{24}$ & IFX & 16 & 20 & 0 & 20 & 0 \\
\hline Inman R. ${ }^{21}$ & IFX & 12 & 39 & 0 & 37 & 0 \\
\hline $\begin{array}{l}\text { Marzo-Ortega } \\
\mathrm{H} .{ }^{32}\end{array}$ & IFX & 30 & 28 & 1 & 14 & 0 \\
\hline Sieper J. ${ }^{30}$ & IFX & 28 & 105 & 0 & 52 & 0 \\
\hline Braun J. ${ }^{35}$ & IFX & 12 & 34 & 1 & 35 & 3 \\
\hline Jennifer D. ${ }^{46}$ & ETN & 16 & 20 & 0 & 20 & 0 \\
\hline Davis J.C. ${ }^{43}$ & ETN & 24 & 138 & 3 & 139 & 8 \\
\hline Brandt J. ${ }^{44}$ & ETN & 6 & 14 & 0 & 16 & 0 \\
\hline Calin A. ${ }^{42}$ & ETN & 12 & 45 & 0 & 39 & 0 \\
\hline $\begin{array}{l}\text { Van der Heijde } \\
\text { D. } 40\end{array}$ & ETN & 12 & 305 & 0 & 51 & 1 \\
\hline
\end{tabular}




\begin{tabular}{|c|c|c|c|c|c|c|}
\hline & & & Trea & & Plac & \\
\hline Barkham N. ${ }^{38}$ & ETN & 12 & 15 & 0 & 17 & 0 \\
\hline Dougados M. ${ }^{39}$ & ETN & 12 & 39 & 0 & 43 & 0 \\
\hline Dougados M. ${ }^{41}$ & ETN & 8 & 42 & 0 & 48 & 0 \\
\hline Dougados M. ${ }^{45}$ & ETN & 12 & 106 & 0 & 109 & 0 \\
\hline Deodhar A. ${ }^{47}$ & IXE & 16 & 212 & 5 & 104 & 0 \\
\hline $\begin{array}{l}\text { Van der Heijde } \\
\text { D. }{ }^{37}\end{array}$ & IXE & 16 & 164 & 1 & 86 & 0 \\
\hline Deodhar A. ${ }^{53}$ & IXE & 52 & 198 & 3 & 104 & 2 \\
\hline Baeten D. ${ }^{51}$ & SEC & 28 & 24 & 0 & 6 & 0 \\
\hline Baeten D. ${ }^{50}$ & SEC & 16 & 394 & 7 & 196 & 2 \\
\hline Pavelka K. ${ }^{49}$ & SEC & 16 & 150 & 0 & 75 & 0 \\
\hline Kivitz A. ${ }^{48}$ & SEC & 16 & 233 & 0 & 117 & 0 \\
\hline Deodhar A. ${ }^{52}$ & SEC & 52 & 369 & 7 & 186 & 2 \\
\hline \multirow[t]{2}{*}{ Giardina A. ${ }^{36}$} & IFX & \multirow[t]{2}{*}{104} & 25 & 1 & $x$ & $\mathrm{x}$ \\
\hline & ETN & & 25 & 2 & $x$ & $x$ \\
\hline
\end{tabular}

\section{Pairwise meta-analysis}

The AU incidence reported in patients with axSpA treated with anti-TNF mAb was significantly lower than with placebo $(O R=0.499, C I 95 \%[0.256-0.973] p=0.041)$. There was no significant difference in AU incidence between ETN (OR $=0.499, \mathrm{Cl} 95 \%[0.198-1,259] \mathrm{p}=0.141)$ or anti-IL17A $(\mathrm{OR}=1,345, \mathrm{CI} 95 \%$ $[0.465-3,886] p=0.585$ ) and placebo (Fig. $3 a, 3 b$ and $3 c$ ). No publication bias is suggested according to the Egger's regression test $(p=0.308)$ for each category of biologic treatment.

Subgroup analyses following pre-specified criteria to compare the incidence of uveitis in each subgroup for each biologic versus placebo showed no significant differences according to axSpA phenotype, disease duration, risk of bias or focus on AU history.

\section{Network meta-analysis}

Incidence of AU flares was lower with anti-TNF mAb compared to placebo (OR = 0.46; IC95\% [0.24-0.90]) (Fig. 4). There was also a significant difference for a decreased incidence of AU with anti-TNF mAb 
compared to anti-IL17A (OR $=0.34 ; \mathrm{CI} 95 \%$ [0.12-0.92]) (Table 3). The other comparisons between biologics, or between biologics and placebo were not significant (Table 3). The Cochran's Q test was 0.57 $(p=0.903)$ ascertaining the absence of heterogeneity/inconsistency between RCTs included.

Table 3

Comparison for the preventive effect on AU flares (OR and 95\% Cl)

\section{Anti-TNF mAb}

$0.8406[0.2953 ; 2.3927] \quad$ Etanercept

$0.3369[0.1240 ; 0.9157]^{*} \quad 0.4008[0.1246 ; 1.2892] \quad$ Anti-IL17A

$0.4647[0.2406 ; 0.8975]^{\star} \quad 0.5528[0.2299 ; 1.3288] \quad 1.3792[0.6357 ; 2.9921] \quad$ Placebo

${ }^{*} \mathrm{p}<0.05$

OR: Odd-Ratio; Cl: Confidence Interval; AU: Anterior Uveitis; TNF: Tumor Necrosis Factor; mAb: monoclonal antibody; IL17A: interleukin-17A

P-scores that measure the mean extent of certainty that a treatment is better than the competing treatments were $0.86,0.728,0.274$ and 0.137 in the anti-TNF mAb, ETN, placebo, and anti-IL17A groups, respectively. Ranking treatments by using P-scores suggested that incidence of AU was the lowest with anti-TNF mAb and the highest with anti-IL17A.

The examination of the funnel plot does not provide suspicion of an asymmetrical distribution of the points representing the studies.

\section{Discussion}

This study of 33 RCTs is, to our knowledge, the first network meta-analysis comparing incidence of AU in both anti-TNF, anti-IL17A, and placebo. Flares of AU were uncommon whatever the treatment with a total of $38 \mathrm{AU}$ events reported under active treatment during controlled periods, for a total cumulative exposure under active treatment of 2265 patients-years. Despite this low incidence, our results showed a significant protective effect on AU flares of anti-TNF mAb compared to placebo and compared to anti-IL17A.

The reduction of $\mathrm{AU}$ incidence rate with anti-TNF mAb compared to placebo or before/after treatment has already been described in various observational studies for IFX, ADA and GOL(7-10, 12, 13). However, unlike in our study, a previous pairwise meta-analysis did not report a protective effect of anti-TNF mAb on $\mathrm{AU}$ flares versus placebo [OR: $0.43,95 \% \mathrm{Cl}: 0.12-1.49, \mathrm{p}=0.18](14)$. This discrepancy can be explained by differences in the inclusion criteria. The Wu et al. pairwise meta-analysis selected RCTs including only patients with AS and RCTs with a follow-up > 12 weeks. When applying our inclusion criteria until February 2014 (limit of their meta-analysis research), we would have included 18 RCTs instead of the 8 RCTs included in their analysis. 
The same pairwise meta-analysis(14) suggested a protective effect on AU flares of ETN compared to placebo, while we did not find any significant difference between the ETN and placebo groups. Our results are confirmed by the conclusions of two randomized placebo-controlled clinical trials where etanercept did not show superiority to placebo in preventing flare rates of uveitis $(54,55)$. As well, the analysis of a large US claims database aimed at comparing the risk of developing uveitis in patients initiating anti-TNF in patients with AS(56) showed that adalimumab and infliximab were associated with a lower incidence of uveitis episodes than etanercept: $2.4 \%$ for adalimumab, $3.2 \%$ for infliximab and $4.5 \%$ for etanercept.

While our results showed that anti-IL17A do not have the same protective effect against AU flares as antiTNF mAb, they are also reassuring with regard to a possible deleterious effect of anti-IL17. without significant difference between anti-IL17 and placebo (OR = 1.38 [CI95\%: 0.63-2.99]). Among anti-IL17A, the incidence rate was 1.69 per 100 PY with SCK and 3.47 per 100 PY with IXE. Incidence of AU with antiIL17A in axSpA has recently been published in a pooled analysis of $3 \mathrm{RCTs}(17)$ assessing SCK with an incidence rate of 1.4 per $100 \mathrm{PY}$, close to our results.

In the pairwise meta-analysis, subgroup analyses did not show any interaction of axSpA phenotype, disease duration or AU history reporting on AU incidence under anti-TNF MAb, ETN or anti-IL17A. In other words, we did not find difference between AS and nr-axSpA, between recent and non-recent ax-SpA and between patients with or without AU history.

The methodological quality of this meta-analysis relies on a double lecture aiming at limiting the risk of errors in selecting studies and extracting data. We obtained 33 homogeneous RCTs, with no publication bias according to funnel plots. This broad selection of RCTs has provided us a total cumulative exposure of 3264 PY. However, despite the number of RCTs included, few comparisons between two active treatments or between an active treatment and placebo are not significant. The absence of statistical difference between different biologic therapies may reflect a real lack of clinical effect but can also be due to a lack of power. This lack of power results from the choice to perform a network meta-analysis imposed to limit extraction of data to the controlled periods. The median duration of placebo (or active)controlled period was 16 weeks, which limits the risk of rare events such as AU.

\section{Conclusion}

In RCTs assessing treatments in axSpA, incident AU are rare events.

This network meta-analysis demonstrates that anti-TNF mAb are associated with a lower incidence of AU flare compared to placebo and to anti-IL17A. The incidence of AU was not increased with anti-IL17A or ETN compared to placebo.

\section{Declarations}

\section{Ethics approval and consent to participate}


Not applicable

\section{Consent for publication}

Not applicable

\section{Availability of data and materials}

The datasets analysed during the current study are available from the corresponding author on reasonable request.

\section{Competing interests}

D.R., M.B. and L.B. have no conflict of interest to declare, P.L. have received research grants or lecture fees from Abbvie, Amgen, Lilly, MSD, Pfizer, and T.P. have received research grants or lecture fees from Abbvie, Amgen, Biogen, Fresenius-Kabi, Lilly, MSD, Novartis, Pfizer, Sandoz, UCB.

\section{Funding}

No funding source to declare

\section{Authors' contributions}

Conception and design of the work: TP, PL, LB. Article selection process: DR, MB. Data collection: DR, MB. Data analysis: $L B$. Data interpretation: $D R, M B, L B, P L, T P$. Drafting the article: $D R, M B, T P$. Critical revision of the article: $D R, M B, L B, P L, T P$. Final approval of the version to be published: $D R, M B, L B, P L, T P$.

\section{Acknowledgements}

We are grateful to the professors and organizers of SMART (Seminars for Meta-Analysis in RheumaTology) for their useful advices. We thank AbbVie who provided logistic support in the organization of sessions about the implementation of meta-analysis and remained independent of the subject choice, study design, collection, analysis, and interpretation of data, the writing of the manuscript or the decision to submit the manuscript for publication. The study was not financially support by AbbVie.

\section{References}

1. Sieper J, Poddubnyy D. Axial spondyloarthritis. Lancet. 1 juill 2017;390(10089):73-84.

2. Garg N, van den Bosch F, Deodhar A. The concept of spondyloarthritis: where are we now? Best Pract Res Clin Rheumatol. oct 2014;28(5):663-72.

3. de Winter JJ, van Mens LJ, van der Heijde D, Landewe R, Baeten DL. Prevalence of peripheral and extra-articular disease in ankylosing spondylitis versus non-radiographic axial spondyloarthritis: a meta-analysis. Arthritis Res Ther. 1 sept 2016;18:196. 
4. Zeboulon N, Dougados M, Gossec L. Prevalence and characteristics of uveitis in the spondyloarthropathies: a systematic literature review. Ann Rheum Dis. juill 2008;67(7):955-9.

5. Jaffe GJ, Dick AD, Brézin AP, Nguyen QD, Thorne JE, Kestelyn P, et al. Adalimumab in Patients with Active Noninfectious Uveitis. N Engl J Med. 8 sept 2016;375(10):932-43.

6. Nguyen QD, Merrill PT, Jaffe GJ, Dick AD, Kurup SK, Sheppard J, et al. Adalimumab for prevention of uveitic flare in patients with inactive non-infectious uveitis controlled by corticosteroids (VISUAL II): a multicentre, double-masked, randomised, placebo-controlled phase 3 trial. Lancet. 17 sept 2016;388(10050):1183-92.

7. Guignard S, Gossec L, Salliot C, Ruyssen-Witrand A, Luc M, Duclos M, et al. Efficacy of tumour necrosis factor blockers in reducing uveitis flares in patients with spondylarthropathy: a retrospective study. Ann Rheum Dis. déc 2006;65(12):1631-4.

8. Braun J, Baraliakos X, Listing J, Sieper J. Decreased incidence of anterior uveitis in patients with ankylosing spondylitis treated with the anti-tumor necrosis factor agents infliximab and etanercept. Arthritis Rheum. août 2005;52(8):2447-51.

9. Lie E, Lindström U, Zverkova-Sandström T, Olsen IC, Forsblad-d'Elia H, Askling J, et al. Tumour necrosis factor inhibitor treatment and occurrence of anterior uveitis in ankylosing spondylitis: results from the Swedish biologics register. Ann Rheum Dis. sept 2017;76(9):1515-21.

10. van Denderen JC, Visman IM, Nurmohamed MT, Suttorp-Schulten MSA, van der Horst-Bruinsma IE. Adalimumab significantly reduces the recurrence rate of anterior uveitis in patients with ankylosing spondylitis. J Rheumatol. sept 2014;41(9):1843-8.

11. Rudwaleit M, Rosenbaum JT, Landewé R, Marzo-Ortega H, Sieper J, van der Heijde D, et al. Observed Incidence of Uveitis Following Certolizumab Pegol Treatment in Patients With Axial Spondyloarthritis. Arthritis Care Res (Hoboken). 2016;68(6):838-44.

12. Faez S, Lobo A-M, Sobrin L, Papaliodis GN. Treatment of seronegative spondyloarthropathyassociated uveitis with golimumab: retrospective case series. Clin Experiment Ophthalmol. juin 2014;42(4):392-5.

13. van Bentum RE, Heslinga SC, Nurmohamed MT, Gerards AH, Griep EN, Koehorst CBJM, et al. Reduced Occurrence Rate of Acute Anterior Uveitis in Ankylosing Spondylitis Treated with Golimumab - The GO-EASY Study. J Rheumatol. 2019;46(2):153-9.

14. Wu D, Guo Y-Y, Xu N-N, Zhao S, Hou L-X, Jiao T, et al. Efficacy of anti-tumor necrosis factor therapy for extra-articular manifestations in patients with ankylosing spondylitis: a meta-analysis. BMC Musculoskelet Disord [Internet]. 10 févr 2015 [cité 27 janv 2020];16(1). Disponible sur: https://www.ncbi.nlm.nih.gov/pmc/articles/PMC4328050/

15. Sharma SM, Jackson D. Uveitis and spondyloarthropathies. Best Pract Res Clin Rheumatol. 2017;31(6):846-62.

16. Dick AD, Tugal-Tutkun I, Foster S, Zierhut M, Melissa Liew SH, Bezlyak V, et al. Secukinumab in the treatment of noninfectious uveitis: results of three randomized, controlled clinical trials. Ophthalmology. avr 2013;120(4):777-87. 
17. Deodhar AA, Miceli-Richard C, Baraliakos X, Marzo-Ortega H, Gladman DD, Blanco R, et al. Incidence of Uveitis in Secukinumab-treated Patients With Ankylosing Spondylitis: Pooled Data Analysis From Three Phase 3 Studies. ACR Open Rheumatol. mai 2020;2(5):294-9.

18. Rudwaleit M, van der Heijde D, Landewé R, Listing J, Akkoc N, Brandt J, et al. The development of Assessment of SpondyloArthritis international Society classification criteria for axial spondyloarthritis (part II): validation and final selection. Ann Rheum Dis. juin 2009;68(6):777-83.

19. Meta-Analysis Manual V3.pdf [Internet]. [cité 20 sept 2020]. Disponible sur: https://www.metaanalysis.com/downloads/Meta-Analysis\%20Manual\%20V3.pdf

20. Rücker G, Schwarzer G, Krahn U, König J. Network Meta-Analysis using Frequentist Methods. 26 juin 2015 [cité 18 sept 2020]; Disponible sur: http://CRAN.R-project.org/package=netmeta

21. Inman RD, Maksymowych WP, CANDLE Study Group. A double-blind, placebo-controlled trial of low dose infliximab in ankylosing spondylitis. J Rheumatol. juin 2010;37(6):1203-10.

22. Deodhar A, Gensler LS, Kay J, Maksymowych WP, Haroon N, Landewé R, et al. A Fifty-Two-Week, Randomized, Placebo-Controlled Trial of Certolizumab Pegol in Nonradiographic Axial Spondyloarthritis. Arthritis \& Rheumatology (Hoboken, NJ). 2019;71(7):1101-11.

23. Sieper J, van der Heijde D, Dougados M, Maksymowych WP, Scott BB, Boice JA, et al. A randomized, double-blind, placebo-controlled, sixteen-week study of subcutaneous golimumab in patients with active nonradiographic axial spondyloarthritis. Arthritis \& Rheumatology (Hoboken, $\mathrm{NJ}$ ). oct 2015;67(10):2702-12.

24. Barkham N, Keen HI, Coates LC, O'Connor P, Hensor E, Fraser AD, et al. Clinical and imaging efficacy of infliximab in HLA-B27-Positive patients with magnetic resonance imaging-determined early sacroiliitis. Arthritis Rheum. avr 2009;60(4):946-54.

25. Huang F, Gu J, Zhu P, Bao C, Xu J, Xu H, et al. Efficacy and safety of adalimumab in Chinese adults with active ankylosing spondylitis: results of a randomised, controlled trial. Ann Rheum Dis. mars 2014;73(3):587-94.

26. van der Heijde D, Kivitz A, Schiff MH, Sieper J, Dijkmans BAC, Braun J, et al. Efficacy and safety of adalimumab in patients with ankylosing spondylitis: results of a multicenter, randomized, doubleblind, placebo-controlled trial. Arthritis Rheum. juill 2006;54(7):2136-46.

27. Sieper J, van der Heijde D, Dougados M, Mease PJ, Maksymowych WP, Brown MA, et al. Efficacy and safety of adalimumab in patients with non-radiographic axial spondyloarthritis: results of a randomised placebo-controlled trial (ABILITY-1). Ann Rheum Dis. juin 2013;72(6):815-22.

28. Inman RD, Davis JC, Heijde D van der, Diekman L, Sieper J, Kim SI, et al. Efficacy and safety of golimumab in patients with ankylosing spondylitis: results of a randomized, double-blind, placebocontrolled, phase III trial. Arthritis Rheum. nov 2008;58(11):3402-12.

29. van der Heijde D, Dijkmans B, Geusens P, Sieper J, DeWoody K, Williamson P, et al. Efficacy and safety of infliximab in patients with ankylosing spondylitis: results of a randomized, placebocontrolled trial (ASSERT). Arthritis Rheum. févr 2005;52(2):582-91. 
30. Sieper J, Lenaerts J, Wollenhaupt J, Rudwaleit M, Mazurov VI, Myasoutova L, et al. Efficacy and safety of infliximab plus naproxen versus naproxen alone in patients with early, active axial spondyloarthritis: results from the double-blind, placebo-controlled INFAST study, Part 1. Ann Rheum Dis. janv 2014;73(1):101-7.

31. Landewé R, Braun J, Deodhar A, Dougados M, Maksymowych WP, Mease PJ, et al. Efficacy of certolizumab pegol on signs and symptoms of axial spondyloarthritis including ankylosing spondylitis: 24-week results of a double-blind randomised placebo-controlled Phase 3 study. Ann Rheum Dis. janv 2014;73(1):39-47.

32. Marzo-Ortega H, McGonagle D, Jarrett S, Haugeberg G, Hensor E, O'connor P, et al. Infliximab in combination with methotrexate in active ankylosing spondylitis: a clinical and imaging study. Ann Rheum Dis. nov 2005;64(11):1568-75.

33. Deodhar A, Reveille JD, Harrison DD, Kim L, Lo KH, Leu JH, et al. Safety and Efficacy of Golimumab Administered Intravenously in Adults with Ankylosing Spondylitis: Results through Week 28 of the GO-ALIVE Study. J Rheumatol. 2018;45(3):341-8.

34. Bao C, Huang F, Khan MA, Fei K, Wu Z, Han C, et al. Safety and efficacy of golimumab in Chinese patients with active ankylosing spondylitis: 1-year results of a multicentre, randomized, double-blind, placebo-controlled phase III trial. Rheumatology (Oxford). sept 2014;53(9):1654-63.

35. Braun J, Brandt J, Listing J, Zink A, Alten R, Golder W, et al. Treatment of active ankylosing spondylitis with infliximab: a randomised controlled multicentre trial. Lancet. 6 avr 2002;359(9313):1187-93.

36. Giardina AR, Ferrante A, Ciccia F, Impastato R, Miceli MC, Principato A, et al. A 2-year comparative open label randomized study of efficacy and safety of etanercept and infliximab in patients with ankylosing spondylitis. Rheumatol Int. sept 2010;30(11):1437-40.

37. van der Heijde D, Cheng-Chung Wei J, Dougados M, Mease P, Deodhar A, Maksymowych WP, et al. Ixekizumab, an interleukin-17A antagonist in the treatment of ankylosing spondylitis or radiographic axial spondyloarthritis in patients previously untreated with biological disease-modifying antirheumatic drugs (COAST-V): 16 week results of a phase 3 randomised, double-blind, active-controlled and placebo-controlled trial. Lancet. 08 2018;392(10163):2441-51.

38. Barkham N, Coates LC, Keen H, Hensor E, Fraser A, Redmond A, et al. Double-blind placebo-controlled trial of etanercept in the prevention of work disability in ankylosing spondylitis. Ann Rheum Dis. nov 2010;69(11):1926-8.

39. Dougados M, Braun J, Szanto S, Combe B, Elbaz M, Geher P, et al. Efficacy of etanercept on rheumatic signs and pulmonary function tests in advanced ankylosing spondylitis: results of a randomised double-blind placebo-controlled study (SPINE). Ann Rheum Dis. mai 2011;70(5):799-804.

40. van der Heijde D, Da Silva JC, Dougados M, Geher P, van der Horst-Bruinsma I, Juanola X, et al. Etanercept $50 \mathrm{mg}$ once weekly is as effective as $25 \mathrm{mg}$ twice weekly in patients with ankylosing spondylitis. Ann Rheum Dis. déc 2006;65(12):1572-7. 
41. Dougados M, Wood E, Combe B, Schaeverbeke T, Miceli-Richard C, Berenbaum F, et al. Evaluation of the nonsteroidal anti-inflammatory drug-sparing effect of etanercept in axial spondyloarthritis: results of the multicenter, randomized, double-blind, placebo-controlled SPARSE study. Arthritis Res Ther. 27 nov 2014;16(6):481.

42. Calin A, Dijkmans B a. C, Emery P, Hakala M, Kalden J, Leirisalo-Repo M, et al. Outcomes of a multicentre randomised clinical trial of etanercept to treat ankylosing spondylitis. Ann Rheum Dis. déc 2004;63(12):1594-600.

43. Davis JC, Van Der Heijde D, Braun J, Dougados M, Cush J, Clegg DO, et al. Recombinant human tumor necrosis factor receptor (etanercept) for treating ankylosing spondylitis: a randomized, controlled trial. Arthritis Rheum. nov 2003;48(11):3230-6.

44. Brandt J, Khariouzov A, Listing J, Haibel H, Sörensen H, Grassnickel L, et al. Six-month results of a double-blind, placebo-controlled trial of etanercept treatment in patients with active ankylosing spondylitis. Arthritis Rheum. juin 2003;48(6):1667-75.

45. Dougados M, van der Heijde D, Sieper J, Braun J, Maksymowych WP, Citera G, et al. Symptomatic efficacy of etanercept and its effects on objective signs of inflammation in early nonradiographic axial spondyloarthritis: a multicenter, randomized, double-blind, placebo-controlled trial. Arthritis \& Rheumatology (Hoboken, NJ). août 2014;66(8):2091-102.

46. Gorman JD, Sack KE, Davis JC. Treatment of ankylosing spondylitis by inhibition of tumor necrosis factor alpha. N Engl J Med. 2 mai 2002;346(18):1349-56.

47. Deodhar A, Poddubnyy D, Pacheco-Tena C, Salvarani C, Lespessailles E, Rahman P, et al. Efficacy and Safety of Ixekizumab in the Treatment of Radiographic Axial Spondyloarthritis: Sixteen-Week Results From a Phase III Randomized, Double-Blind, Placebo-Controlled Trial in Patients With Prior Inadequate Response to or Intolerance of Tumor Necrosis Factor Inhibitors. Arthritis \& Rheumatology (Hoboken, NJ). 2019;71(4):599-611.

48. Kivitz AJ, Wagner U, Dokoupilova E, Supronik J, Martin R, Talloczy Z, et al. Efficacy and Safety of Secukinumab 150 mg with and Without Loading Regimen in Ankylosing Spondylitis: 104-week Results from MEASURE 4 Study. Rheumatol Ther. déc 2018;5(2):447-62.

49. Pavelka K, Kivitz A, Dokoupilova E, Blanco R, Maradiaga M, Tahir H, et al. Efficacy, safety, and tolerability of secukinumab in patients with active ankylosing spondylitis: a randomized, doubleblind phase 3 study, MEASURE 3. Arthritis Res Ther. 22 2017;19(1):285.

50. Baeten D, Sieper J, Braun J, Baraliakos X, Dougados M, Emery P, et al. Secukinumab, an Interleukin17A Inhibitor, in Ankylosing Spondylitis. N Engl J Med. 24 déc 2015;373(26):2534-48.

51. Baeten D, Baraliakos X, Braun J, Sieper J, Emery P, van der Heijde D, et al. Anti-interleukin-17A monoclonal antibody secukinumab in treatment of ankylosing spondylitis: a randomised, doubleblind, placebo-controlled trial. Lancet. 23 nov 2013;382(9906):1705-13.

52. Deodhar A, Blanco R, Dokoupilová E, Hall S, Kameda H, Kivitz AJ, et al. Secukinumab improves signs and symptoms of non-radiographic axial spondyloarthritis: primary results of a randomized controlled phase III study. Arthritis \& Rheumatology (Hoboken, NJ). 7 août 2020; 
53. Deodhar A, van der Heijde D, Gensler LS, Kim T-H, Maksymowych WP, Østergaard M, et al. Ixekizumab for patients with non-radiographic axial spondyloarthritis (COAST-X): a randomised, placebocontrolled trial. Lancet. 04 2020;395(10217):53-64.

54. Foster CS, Tufail F, Waheed NK, Chu D, Miserocchi E, Baltatzis S, et al. Efficacy of etanercept in preventing relapse of uveitis controlled by methotrexate. Arch Ophthalmol. avr 2003;121(4):437-40.

55. Smith JA, Thompson DJS, Whitcup SM, Suhler E, Clarke G, Smith S, et al. A randomized, placebocontrolled, double-masked clinical trial of etanercept for the treatment of uveitis associated with juvenile idiopathic arthritis. Arthritis Rheum. 15 févr 2005;53(1):18-23.

56. Wendling D, Joshi A, Reilly P, Jalundhwala YJ, Mittal M, Bao Y. Comparing the risk of developing uveitis in patients initiating anti-tumor necrosis factor therapy for ankylosing spondylitis: an analysis of a large US claims database. Curr Med Res Opin. déc 2014;30(12):2515-21.

\section{Figures}

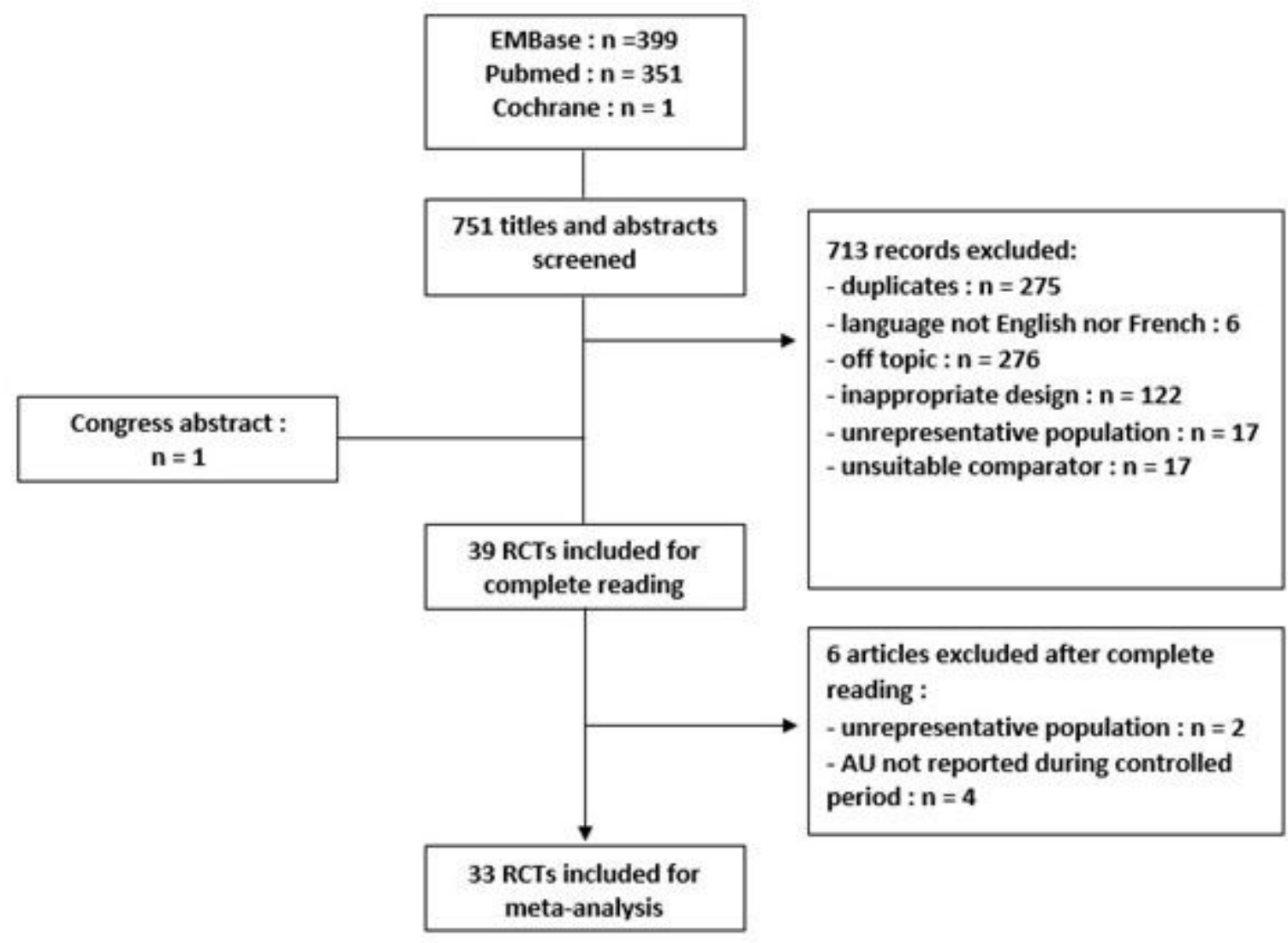

\section{Figure 1}

Study selection process (Flowchart) 


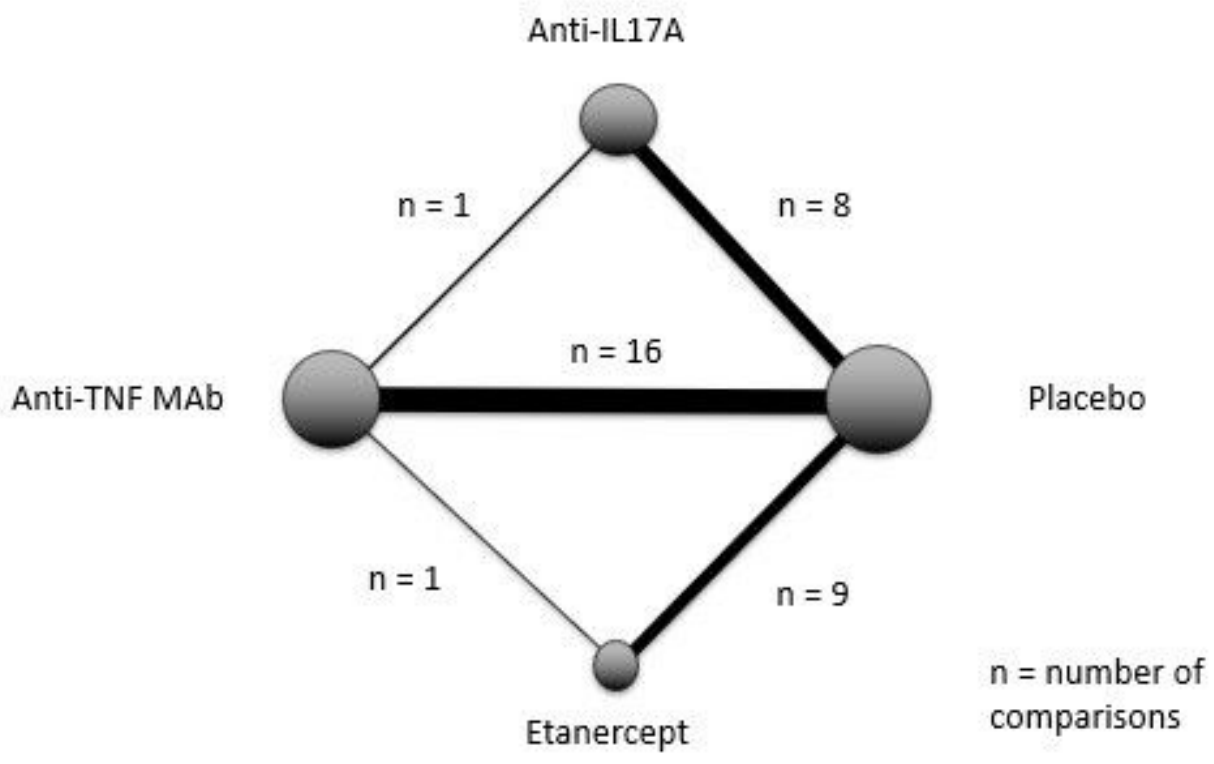

\section{Figure 2}

Network configuration of eligible comparisons Nodes represent each intervention with a size proportional to the number of patients receiving treatment. Lines represent direct comparisons, the more patients involved in comparison the thicker the line. TNF: Tumor Necrosis Factor; mAb: monoclonal antibody; ETN: etanercept; IL17A: interleukin-17A 


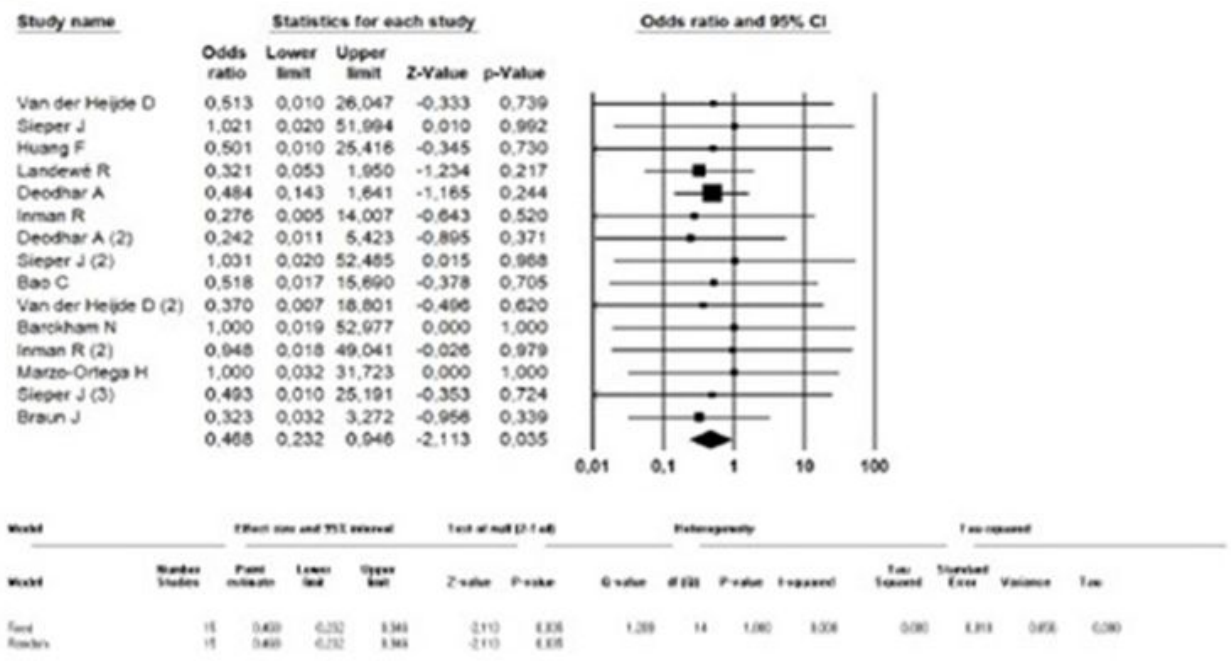

3b

\begin{tabular}{|c|c|c|c|c|c|}
\hline \multirow[t]{2}{*}{ Study name } & \multirow[b]{2}{*}{$\begin{array}{l}\text { Odds } \\
\text { rabo }\end{array}$} & \multicolumn{4}{|c|}{ Statistics for each study } \\
\hline & & $\begin{array}{c}\text { Lowet } \\
\text { Imin }\end{array}$ & Uppet & Z-Value & p.Value \\
\hline Jemniter D Gorman & 1.000 & 0.019 & 52.977 & 0.000 & 1.000 \\
\hline Devis JC & 0.364 & 0.034 & 1,402 & $-1,469$ & 0,142 \\
\hline Brandt J & 1,140 & 0,021 & 61,093 & 0,068 & 0,946 \\
\hline $\operatorname{Caln} A$ & 0.865 & 0.017 & 44,648 & -0.072 & 0.943 \\
\hline Ven der Heise D & 0.090 & 0.003 & 2.969 & $-1,334$ & 0.102 \\
\hline Berkham $N$ & 1,138 & 0.021 & 61,076 & 0.064 & 0.949 \\
\hline Dougesos M & 1.104 & 0.021 & 56.995 & 0.049 & 0.961 \\
\hline Doupesos M (2) & 1,145 & 0,022 & 56.970 & 0.067 & 0,946 \\
\hline \multirow[t]{2}{*}{ Dougudos M (3) } & 1,028 & 0.020 & 52.305 & 0.014 & 0.969 \\
\hline & 0.500 & 0,195 & 1,331 & $-1,3 n$ & 0,168 \\
\hline
\end{tabular}

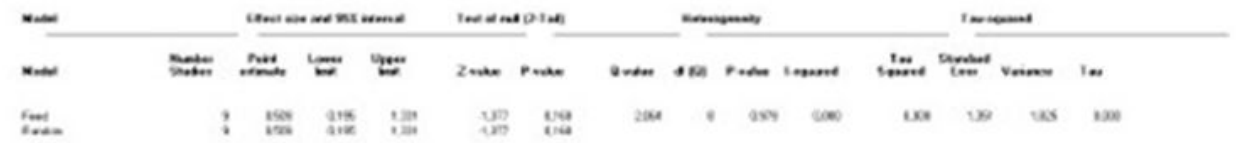

$3 c$
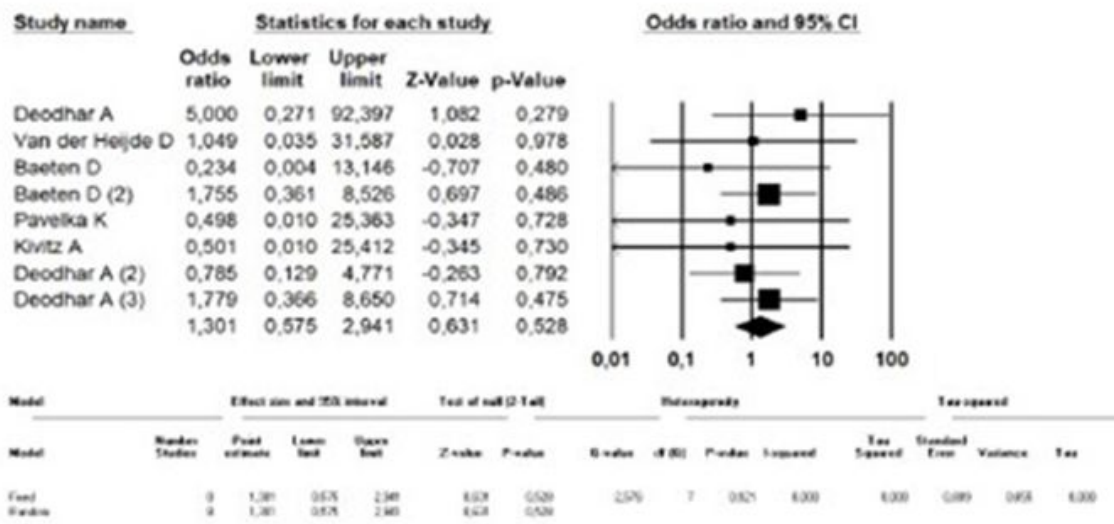

Figure 3

Pairwise meta-analysis. 3a: Pairwise meta-analysis anti-TNF mAb versus placebo; 3b: Pairwise metaanalysis ETN versus placebo; 3c: Pairwise meta-analysis anti-IL17A versus placebo TNF: Tumor Necrosis Factor; mAb: monoclonal antibody; ETN: etanercept; IL17A : interleukin-17A 


\section{Comparisons: biologics versus placebo}

Treatment

(Mantel-Haenszel Method)

OR $\quad 95 \%-\mathrm{Cl}$

Anti-TNF MAb

Etanercept

Anti-IL17A

Placebo

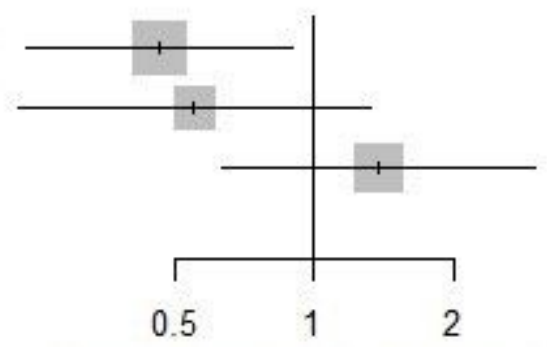

$0.46[0.24 ; 0.90]$

$0.55[0.23 ; 1.33]$

$1.38[0.64 ; 2.99]$

1.00

Favours Others Favours Placebo

\section{Figure 4}

Forest plots of network meta-analysis of all trials for AU incidence

\section{Supplementary Files}

This is a list of supplementary files associated with this preprint. Click to download.

- ADDITIONALfile2.docx

- additionalfile1.docx

- additionalfile3.docx 